\title{
Cardiac Arrhythmias in a Septic ICU Population: A Review
}

\author{
Andrei Schwartz\#, Evgeni Brotfain\#*, Leonid Koyfman, Moti Klein \\ Department of Anesthesiology and Critical Care, General Intensive Care Unit, Soroka Medical Center, Ben-Gurion \\ University of the Negev, Beer Sheva, Israel
}

\begin{abstract}
Progressive cardiovascular deterioration plays a central role in the pathogenesis of multiple organ failure (MOF) caused by sepsis. Evidence of various cardiac arrhythmias in septic patients has been reported in many published studies. In the critically ill septic patients, compared to non-septic patients, new onset atrial fibrillation episodes are associated with high mortality rates and poor outcomes, amongst others being new episodes of stroke, heart failure and long vasopressor usage. The potential mechanisms of the development of new cardiac arrhythmias in sepsis are complex and poorly understood. Cardiac arrhythmias in critically ill septic patients are most likely to be an indicator of the severity of pre-existing critical illness.
\end{abstract}

Keywords: cardiac arrhythmias, new-onset atrial fibrillation, sepsis, septic shock

Received: 17 June 2015 / Accepted: 15 September 2015

\section{INTRODUCTION}

The systemic inflammatory response syndrome to infection (SIRS) is one of the most important causes of morbidity and mortality in critically ill patients $[1,2]$. Progressive cardiovascular deterioration plays a central role in the pathogenesis of multiple organ failure (MOF) caused by sepsis [3-5]. Cardiovascular compromise in sepsis has been described in relation to blood pressure levels and vasopressors' requirement. Moreover, animal studies and human observations [68] have indicated that myocardial dysfunction occurs globally. Sepsis-related myocardial dysfunction does not relate to myocardial ischemia or necrosis but is associated with cytokine-induced myocardial depression [5] and myocardial oedema, the later due to increased vascular permeability and leakage $[9,10]$. In sepsis both systolic and diastolic bi-ventricular myocardial dysfunction may be present $[1,11,12]$. Several authors described the autonomic system dysfunction as part of myocardial dysfunction pathogenesis in the systemic inflammatory response syndrome [13-20]. It is characterized by a reduction in heart rate variability due to loss of the balance and attenuation in both sympathetic and vagal signals [15]. In the presence of severe pro-inflammatory response in SIRS patients, the cholinergic vagal activity is abnormally increased by sympathetic tone resulting in increased heart rates [13-16]. Such sepsis-related tachycardia might lead to tachycardia-related cardiomyopathy and significant myocardial dysfunction.

Evidence of various cardiac arrhythmias in septic patients has been demonstrated by several clinical reports and studies [21-25]. These arrhythmias may be explained by autonomic dysfunction or impairment and involvement of the cardiac conduction system rather than to pre-existing cardiac co-morbidities [26,27].

This paper will focus on clinical features of arrhythmias and potential pathophysiologic mechanisms of the cardiac conduction system disturbances in septic patients.

\section{PREVALENCE AND RISK FACTORS}

The clinical evidence and significance of cardiac arrhythmias as an early sign of sepsis were first described by Kirkpatrick et al in 1973 [28]. Since then, differ-

\footnotetext{
Correspondence to: Evgeni Brotfain, Department of Anesthesiology and Critical Care, Soroka Medical Center, Ben Gurion University of the Negev, POB 151, Beer Sheva, Israel. E-mail: bem1975@gmail.com

Andrei Schwartz: Department of Anesthesiology and Critical Care, Soroka Medical Center, Ben Gurion University of the Negev, POB 151, Beer Sheva, Israel. E-mail: schwartz72@hotmail.com Leonid Koyfman: Department of Anesthesiology and Critical Care, Soroka Medical Center, Ben Gurion University of the Negev, POB 151, Beer Sheva, Israel. E-mail: leonidko@gmail.com Moti Klein: Department of Anesthesiology and Critical Care, Soroka Medical Center, Ben Gurion University of the Negev, POB 151, Beer Sheva, Israel. E-mail: motik@clalit.org.il

Drs. Schwartz and Brotfain contributed equally to the paper.
} 
ent types of supra-ventricular, ventricular arrhythmic tachycardia and arrhythmic bradycardia in septic critically ill patients have been described [21,29-32] (Table 1). Several large epidemiological [24,25,33-35] and small cohort studies [36-39] have shown strong evidence of new onset arrhythmic tachycardia immediately before the onset of postoperative sepsis. Most of clinical data has been based on mixed ICU populationinvestigations and evaluated higher rates of prevalence of supraventricular cardiac arrhythmic tachycardia (8$13.6 \%)[37,40-44]$ rather than ventricular arrhythmic tachycardia $(\sim 2 \%)[40,43]$.

Atrial fibrillation has been demonstrated as the most common arrhythmia associated with sepsis and septic shock [36,37,41,44]. Christian et al [22] investigated a mixed ICU population and showed evidence of new AF in about $5.8 \%$ of septic patients. New atrial fibrillation episodes were established more frequently in surgical than in medical patients [7.7\% vs $5.4 \%]$. Salman et al [37] and Arora et al [38] reported that new paroxysmal atrial fibrillation accounts for up to $30 \%$ of all arrhythmic episodes related to sepsis. Walkey et al [24] demonstrated that new onset AF associated with sepsis was encountered in $14 \%$ of all hospital-associated AF events. Risk factors predisposing to the development of new onset arrhythmic tachycardia include pre-existing factors such as chronic heart failure, valvular heart disease, coronary artery disease and endocrine disease, as well as acute metabolic disturbances such as electrolyte abnormalities: hypophosphatemia or hypomagnesaemia, severity of sepsis and vasopressors usage [35,39,42,45].

Salman et al [37] found a strong correlation between paroxysmal atrial fibrillation (PAF) episodes and advanced age, previous medical history of PAF, high severity illness and low left ventricular ejection fraction. Christian et al [22] described advanced age as a major risk factors for the development of atrial fibrillation in septic sixty five years old patients. Other risk factors for new onset AF have been associated with gender (male), a history of hypertension and a SOFA score in the ICU higher than $12[35,39,42,43]$.

\section{EPIDEMIOLOGY}

Epidemiologically, most septic patients who developed new atrial fibrillation were in septic shock [22]. Pneumonia was shown to be the most likely source of infection in septic patients with new atrial fibrillation [22].
Other sources of sepsis presented less frequently [22] and only rarely did septic patients have multiple sites of infection [22].

Both Meierhenrich et al [23] and Walkey et al [24] demonstrated a high prevalence of patients with septic shock. Walkey et al [24] pointed out that in patients with new onset AF, there existed a higher respiratory tract infection prevalence (49\%) compared to other sources of sepsis such as urinary $(40.3 \%)$, primary bacteremia (32.8\%), abdominal (25.4\%) or skin $\backslash$ soft tissue (7.9\%). Gram-positive sepsis was associated more frequently $(28.4 \%)$ with new onset AF than gram-negative (23.4\%) and fungal pathogens sepsis (1.6-3.6\%) [24].

\section{MORBIDITY AND MORTALITY}

New onset atrial fibrillation episodes were associated with high mortality rates in critically ill septic patients compared to non-septic persons [22-24,37,40].

Christian et al [22] observed a mortality rate of $68.8 \%$ in patients with new AF compared with $39.8 \%$ in patients with no arrhythmias. Annane et al [40] reported a mortality rate of $20 \%$ in ICU septic persons. Meierhenrich et al [23] assessed mortality rates in an ICU population at 28 and 60 days and demonstrated a trend towards increase mortality in arrhythmic individuals with septic shock. Overall ICU mortality was $44 \%, 28$ day mortality $39 \%$ and 60 day mortality was $48 \%$ in patients with septic shock, compared to nonseptic shock patients with AF who presented 15\%, 15\% and $23 \%$ mortality rates over the same periods, and to septic individuals with sustained sinus rhythm, who presented mortality rates of $22 \%, 22 \%$ and $26 \%$ respectively, again over the same periods. This study showed that the arrhythmic group compared to those with sustained sinus rhythm and to those with new onset AF without shock, were detained for longer periods in an ICU.

Mortality rates were also higher in individuals with severe sepsis and new onset AF (56.3\%) compared to patients with pre-existing $\mathrm{AF}(43.8 \%)$ or without new onset AF (38.2\%) [24]. However, Koyfman et al [46] found no difference in ICU mortality rate between septic patients who had previous AF episodes and patients with no previous past medical history of any type of cardiac arrhythmias.

New onset AF was found to correlate with new neurologic compromise. Annane et al [40] showed that both atrial fibrillation (15\%) and ventricular ar- 
rhythmias (38\%) in ICU populations were significant ly correlated with new neurologic events such as focal neurological deficit or diffuse axon injury, compared to patients without arrhythmias (6\%). Walkey et al [24] reported a higher occurrence of in-hospital strokes in severe sepsis individuals with new onset AF (2.6\%) compared with pre-existing $\mathrm{AF}(0.57 \%)$ and patients without AF (0.69\%). New-onset supraventricular arrhythmia was associated with longer catecholamine use during septic shock compared with patients in sinus rhythm [47].

In another study Walkey et al [25] reported that patients with new-onset AF during sepsis have increased long-term risks of heart failure, ischemic stroke, and death after cessation of treatment for sepsis. High risk of ischemic stroke in septic patients with new onset AF was argued and explained by potential haemodynamic collapse, coagulopathy and inflammatory reaction.

\section{POTENTIAL MECHANISMS OF CARDIAC ARRHYTHMIAS AND CARDIAC CONDUC- TION SYSTEM DYSFUNCTION IN SEPSIS.}

As atrial fibrillation is the most frequent heart rate irregularity in the septic critically ill population, further discussion will concentrate on its potential pathophysiological pathways. The development of cardiac arrhythmias is associated with evidence of three factors: the arrhythmogenic substrate, the trigger factors and the modulation factors such as autonomic nervous system or inflammation [48]. Triggered activity has been shown in the musculature of all atrial structures. An imbalance

Table 1. Overview of the incidence of new onset cardiac arrhythmias in septic ICU patients

\begin{tabular}{|c|c|c|c|c|c|c|}
\hline Author & $\begin{array}{l}\text { Study } \\
\text { design }\end{array}$ & Location & Population & $\begin{array}{c}\text { Cardiac } \\
\text { arrhythmia types }\end{array}$ & $\begin{array}{c}\text { Occurrence } \\
(\%)\end{array}$ & $\begin{array}{c}\text { Mortality } \\
(\%)\end{array}$ \\
\hline $\begin{array}{l}\text { Bender et al } \\
{[36], 1996}\end{array}$ & $\begin{array}{l}\text { Retrospective, } \\
\text { single center }\end{array}$ & GICU & mixed* & SVT & 13.6 & 28.6 \\
\hline $\begin{array}{c}\text { Braitwaite et al } \\
\text { [35], } 1998\end{array}$ & $\begin{array}{l}\text { Prospective, } \\
\text { observational } \\
\text { single center }\end{array}$ & $\begin{array}{l}\text { Surgical } \\
\text { ICU }\end{array}$ & mixed* & $\begin{array}{c}\text { atrial } \\
\text { arrhythmias }\end{array}$ & 10.2 & 23.4 \\
\hline $\begin{array}{l}\text { Reinelt et al } \\
\text { [34], } 2001\end{array}$ & $\begin{array}{l}\text { Prospective } \\
\text { single center }\end{array}$ & $\begin{array}{c}\text { Medical } \\
\text { cardiological } \\
\text { ICUs }\end{array}$ & $\begin{array}{c}\text { mixed* } \\
\text { postoperative }\end{array}$ & & $15.7-19.2$ & 30.8 \\
\hline $\begin{array}{l}\text { Seguin et al } \\
\text { [42], } 2004\end{array}$ & $\begin{array}{l}\text { Prospective } \\
\text { observational }\end{array}$ & $\begin{array}{l}\text { Surgical ICU } \\
\text { single center }\end{array}$ & mixed* & $\begin{array}{c}\text { Atrial } \\
\text { fibrillation }\end{array}$ & 5.3 & 37.5 \\
\hline $\begin{array}{c}\text { Goodman et al } \\
\text { [41], } 2007\end{array}$ & $\begin{array}{l}\text { Prospective } \\
\text { single center }\end{array}$ & GICU & mixed* & $\begin{array}{c}\text { Atrial fibrillation, } \\
\text { flutter }\end{array}$ & 9 & 54 \\
\hline $\begin{array}{c}\text { Arora et al } \\
\text { [38], } 2007\end{array}$ & $\begin{array}{l}\text { Prospective } \\
\text { single center }\end{array}$ & GICU & mixed* & $\begin{array}{c}\text { Atrial } \\
\text { fibrillation }\end{array}$ & 29.5 & \\
\hline $\begin{array}{c}\text { Salman et al } \\
\text { [37], } 2008\end{array}$ & $\begin{array}{l}\text { Retrospective } \\
\text { single center }\end{array}$ & GICU & mixed & PAF & 31 & \\
\hline $\begin{array}{c}\text { Christian et al } \\
\text { [22], } 2008 \\
\end{array}$ & $\begin{array}{l}\text { Retrospective } \\
\text { single center }\end{array}$ & GICU & septic & $\begin{array}{c}\text { Atrial } \\
\text { fibrillation }\end{array}$ & 5.8 & 68.8 \\
\hline $\begin{array}{c}\text { Annane et al } \\
\text { all } \\
{[14], 2008}\end{array}$ & $\begin{array}{c}\text { Prospective } \\
\text { multicenter } \\
\text { (Europe) }\end{array}$ & GICUs & mixed* & & 14 & 29 \\
\hline $\begin{array}{c}\text { Meierhenrichet } \\
\text { al [23], } 2010\end{array}$ & $\begin{array}{l}\text { Prospective } \\
\text { single center }\end{array}$ & Surgical ICU & $\begin{array}{l}\text { Sepsis/septic } \\
\text { shock }\end{array}$ & $\begin{array}{c}\text { Atrial } \\
\text { fibrillation }\end{array}$ & 7.8 & $15 \backslash 22$ \\
\hline $\begin{array}{c}\text { Walkey et al } \\
\text { [24], } 2011\end{array}$ & $\begin{array}{l}\text { Retrospective } \\
\text { multicenter }\end{array}$ & $\begin{array}{l}\text { Nonfederal } \\
\text { acute care } \\
\text { (California } \\
\text { hospitals) }\end{array}$ & $\begin{array}{l}\text { Sepsis/sepsis } \\
\text { with MOF }\end{array}$ & $\begin{array}{c}\text { Atrial } \\
\text { fibrillation }\end{array}$ & 5.9 & 56 \\
\hline $\begin{array}{l}\text { Walkey et al } \\
\text { [25], } 2014\end{array}$ & $\begin{array}{l}\text { Retrospective } \\
\text { multicenter }\end{array}$ & GICUs & sepsis & $\begin{array}{c}\text { Atrial } \\
\text { fibrillation }\end{array}$ & 7 & 44 \\
\hline $\begin{array}{c}\text { Seemann et al } \\
\text { [47], } 2015\end{array}$ & $\begin{array}{l}\text { Prospective } \\
\text { single center }\end{array}$ & GICU & $\begin{array}{l}\text { Sepsis/septic } \\
\text { shock }\end{array}$ & $\begin{array}{c}\text { Atrial } \\
\text { fibrillation }\end{array}$ & 42 & 42 \\
\hline
\end{tabular}


in autonomic nervous system activity has been suggested as one of the responsive mechanisms associated with the development of heart irregularities. [48-50]

One explanation of the development of new onset atrial fibrillation events in sepsis is the imbalance between sympathetic and vagal tone in sepsis leading to a reduction of heart rate variability (HRV) [3,51]. In a study on human atrial cardiomyocytes, Zorn-Pauly et al [26] identified a gram-negative bacteria -endotoxin-induced I(f) impairment, which might contribute to a reduced responsiveness to both sympathetic and vagal autonomic stimuli. It might be argued that decreased responsiveness to autonomic stimuli would affect HRV [52]. Decreased vagal response seems to be extremely important and pathologic in view of ability of vagal stimulation to prevent inflammatory response [53]. Thus, sepsis-related increased catecholamine level might override the endotoxin I(f) blockade. In support of this view, the authors point out an enhanced response of pacemaker current to $\beta$-adrenergic stimulation. However, the precise mechanism of LPS-endotoxin action on the pacemaker current has not been identified. Therefore, it can be hypothesized that the sinoatrial node pacemaker cells, highly sensitized by massive $\beta 1$-adrenergic catecholamine stimulation, due to endogenous released or treatment related, results in a high heart rate output, commonly described as sepsis-related tachycardia.

The significance of the inflammatory component in the development of new atrial fibrillation events has also been supported by the existence of a strong correlation between the elevation of C-reactive protein, IL-6 and TNF- $\alpha$ blood levels and the onset of AF [54].

Unopposed sustained atrial tachycardia during the sepsis or septic shock will further increase calcium influx through L-type $\mathrm{Ca}^{2+}$ channels. With each action potential, $\mathrm{Ca}^{2+}$ enters the cell through L-type $\mathrm{Ca}^{2+}$ channels. Calcium $\left(\mathrm{Ca}^{2+}\right)$ influx through the L-type $\mathrm{Ca}^{2+}$ channels is the main current which produces the plateau phase of the atrial action potential.

Increased intracellular calcium load leads to marked shortening of the atrial refractory period and elicited triggered activity. These changes may facilitate the AF mechanism $[48,55]$. Moreover, recent data from animal studies [56-60] showed an enhanced response of the Ltype calcium current to $\beta$-adrenergic stimulation, after endotoxin application. B-Adrenergic receptor activation also increases channel activity by prolonging the open time and shortening the close time of $\mathrm{Ca}^{2+}$ chan- nels. In addition, $\beta$-adrenoceptor activation increases the probability that a channel will open, as reflected by an increase in the number of channel openings per unit time during single-channel recording [59].

Abi-Gerges et al [60] reported the density of $\mathrm{I}(\mathrm{Ca})$ progressively decreased at 12 and 36 hours after EDTX injection. However, the dihydropyridine (+/-)Bay K $8644(100 \mathrm{nM})$ enhanced $\mathrm{I}(\mathrm{Ca})$ to levels similar to those in control and EDTX-treated myocytes. In addition, the net stimulatory effect of a beta-adrenergic agonist (isoproterenol) on $\mathrm{I}(\mathrm{Ca})$ was increased 12 hours after EDTX injection. This change in the beta-adrenergic effect declined 24 hours later. The antiadrenergic effect of acetylcholine on $\mathrm{I}(\mathrm{Ca})$ was unchanged 12 hours after EDTX injection, but increased 36 hours after EDTX injection. A similar finding was obtained in guinea pig hearts as early as four hours after EDTX injection [59]. These findings might explain the high sensitivity of cardiac pacemaker cells to positive inotropic effect of adrenergic stimulation and most likely development of new AF episode especially in the early stages of sepsis.

\section{口 CLINICAL STRATEGY IN SEPSIS-INDUCED CARDIAC ARRHYTHMIAS}

New onset atrial fibrillation events in septic patients indicate a diversity of clinical strategies. It should be considered as a sign of the early SIRS $[21,29,41]$. It follows that patient care may be enhanced by continuous cardiovascular monitoring and simple daily 12-lead ECG in addition to clinical exams and laboratory findings.

Second, it may to be an important prognostic sign. It is correlated with increasing mortality and new neurologic events $[23,24,40]$. Thus, keeping it in mind, the heart-rate variability performance might become a relevant part of the clinical assessment in potentially septic patients $[15,61]$.

A new AF event needs to be treated by electrical (synchronized shock) or pharmacological (amiodarone) cardioversion. It should be delayed by antiarrhythmic therapy such as $\beta$-blockers or Ca channel blockers. Amiodarone has a lesser negative inotropic and proarrhythmic effect and was found to be the single most frequently used drug for controlling arrhythmic tachycardia [23].

In contrast, Walkey et al [25], studied the initial types of treatment used for treatment of new onset AF in septic patients. The report indicated that beta- 
blockers were associated with better clinical outcomes compared to calcium channel-blockers, digoxin, or Amiodarone.

Importantly, the inability to restore sinus rhythm was strongly correlated with ICU mortality. It should be well understood that the inability to restore sinus rhythm could compromise acutely patient's haemodynamic status and even increase mortality, though the restoration of sinus rhythm in septic patients does not automatically imply an improvement in clinical outcome.

\section{- CONCLUSIONS}

Management of arrhythmias is undoubtedly one of the major problems in emergency and critical care medicine and is associated with a decline in prognosis and deterioration in clinical outcome. Arrhythmias are rarely recorded at the point of admission to an ICU, usually being first noted during the ICU stay. Cardiac arrhythmias in critically ill patients are most likely an indicator of severity of pre-existing critical illness rather than independent on-going pathophysiological process.

\section{REFERENCES}

1. Krishnagopalan S, Kumar A, Parrillo JE, Kumar A. Myocardial dysfunction in the patient with sepsis. Curr Opin Crit Care. 2002;8:376-88.

2. Rangel-Faustro MS. The epidemiology of bacterial sepsis. Infect Dis Clin North Am. 1999,13:299-311.

3. Muller-Werdan $U$, Buerke $M$, Ebelt $H$, et al. Septic cardiomyopathy - A not yet discovered cardiomyopathy? Exp Clin Cardiol. 2006;11:226-236.

4. Parrillo JE. The cardiovascular pathophysiology of sepsis. Annu Rev Med. 1989;40:469-85.

5. Zanotti-Cavazzoni SL, Hollenberg SM. Cardiac dysfunction in severe sepsis and septic shock. Curr Opin Crit Care. 2009;15:392-7.

6. Parker MM, Shelhamer JH, Bacharach SL, et al. Profound but reversible myocardial depression in patients with septic shock. Ann Intern Med. 1984;100:483-90.

7. Ognibene FP, Parker MM, Natanson C, et al. Depressed left ventricular performance. Response to volume infusion in patients with sepsis and septic shock. Chest. 1988;93:903-10.

8. Parker MM, McCarthy KE, Ognibene FP, Parrillo JE. Right ventricular dysfunction and dilatation, similar to left ventricular changes, characterize the cardiac depression of septic shock in humans. Chest. 1990;97:126-31.
9. Chagnon F, Bentourkia M, Lecomte R, Lessard M, Lesur O. Endotoxin-induced heart dysfunction in rats: assessment of myocardial perfusion and permeability and the role of fluid resuscitation. Crit Care Med. 2006;34:127-33.

10. Yu P, Boughner DR, Sibbald WJ, K, Dunmore J, Martin CM. Myocardial collagen changes and edema in rats with hyperdynamic sepsis. Crit Care Med. 1997; 25:657-62.

11. Stahl TJ, Alden PB, Ring WS, Madoff RC, Cerra FB. Sepsisinduced diastolic dysfunction in chronic canine peritonitis. Am J Physiol. 1990;258:625-33.

12. Natanson C, Fink MP, Ballantyne HK, MacVittie TJ, Conklin JJ, Parrillo JE. Gram-negative bacteremia produces both severe systolic and diastolic cardiac dysfunction in a canine model that simulates human septic shock. J Clin Invest. 1986;78:259-70.

13. Sharshar T, Gray F, Lorin de la Grandmaison G, et al. Apoptosis of neurons in cardiovascular autonomic centres triggered by inducible nitric oxide synthase after deathfrom septic shock. Lancet. 2003;362:1799-805.

14. Annane D, Trabold F, Sharshar T, et al. Inappropriate sympathetic activation at onset of septic shock: A spectral analysis approach. Am J Respir Crit Care Med. 1999;160:458-65.

15. Schmidt HB, Werdan K, Müller-Werdan U. Autonomic dysfunction in the ICU patient. Curr Opin Crit Care. 2001;7:31422.

16. Schmidt H, Müller-Werdan $U$, Hoffmann T, et al. Autonomic dysfunction predicts mortality in patients with multiple organ dysfunction syndrome of different age groups. Crit Care Med. 2005;33:1994-2002.

17. Godin PJ, Buchman TG. Uncoupling of biological oscillators: A complementary hypothesis concerning the pathogenesis of multiple organ dysfunction syndrome. Crit Care Med. 1996;24:1107-16.

18. Seely AJ, Christou NV. Multiple organ dysfunction syndrome: Exploring the paradigm of complex nonlinear systems. Crit Care Med. 2000;28:2193-200.

19. Marshall JC. Complexity, chaos, and incomprehensibility: Parsing the biology of critical illness. Crit Care Med. 2000;28:2646-8.

20. Godin PJ, Fleisher LA, Eidsath A, et al. Experimental human endotoxemia increases cardiac regularity: Results from a prospective, randomized, crossover trial. Crit Care Med 1996;24:1117-24.

21. Goodman S, Weiss Y, Weissman C.Update on cardiac arrhythmias in the ICU. Curr Opin Crit Care. 2008;14:549-54.

22. Christian SA, Schorr C, Ferchau L, Jarbrink ME, Parrillo JE, Gerber DRJ. Clinical characteristics and outcomes of septic patients with new-onset atrial fibrillation. Crit Care. 2008;23:532-6.

23. Meierhenrich R, Steinhilber E, Eggermann C, et al. Incidence and prognostic impact of new-onset atrial fibrillation in patients with septic shock: a prospective observational study. Crit Care. 2010;14:108-12.

24. Walkey AJ, Wiener RS, Ghobrial JM, Curtis LH, Benjamin EJ. Incident stroke and mortality associated with new-onset atrial fibrillation in patients hospitalized with severe sepsis. JAMA. 
Available online at: www.jccm.ro

2011;23:2248-54.

25. Walkey AJ, Evans SR, Winter MR, Benjamin EJ. Practice patterns and outcomes of treatments for atrial fibrillation during sepsis: A propensity-matched cohort study. Chest. 2015;13:1-10.

26. Zorn-Pauly K, Pelzmann B, Lang P, et al. Endotoxin impairs the human pacemaker current If. Shock. 2007;28:655-61.

27. Zhong J, Hwang TC, Adams HR, Rubin LJ. Reduced L-type calcium current in ventricular myocytes from endotoxemic guinea pigs. Am J Physiol. 1997,23:12-24.

28. Kirkpatrick JR, Heilbrunn A, Sankaran S. Cardiac arrhythmias: an early sign of sepsis. Am Surg. 1973;39:380-2.

29. Trappe HJ, Brandts B, Weismueller P. Arrhythmias in the intensive care patient. Curr Opin Crit Care. 2003;9:345-55.

30. Reinelt P, Karth GD, Geppert A, et al. Incidence and type of cardiac arrhythmias in critically ill patients: a single center experience in a medical-cardiological ICU. Intensive Care Med. 2001;27:1466-73.

31. Lampert R, Ezekowitz M. Management of arrhythmias. Clin Geriatr Med. 2000;16:593-618.

32. Baine WB, Yu M, Weis KA. Trends and outcomes in the hospitalization of older Americans for cardiac conduction disorders or arrhythmias, 1991-1998. J Am Geratr Soc. 2001;49:763-70.

33. Artucio H, Pereira M. Cardiac arrhythmias in critically ill patients: epidemiologic study. Crit Care Med. 1990;18:1383-8.

34. Reinelt P, Karth GD, Geppert A, Heinz G. Incidence and type of cardiac arrhythmias in critically ill patients: a single center experience in a medical-cardiological ICU. Intensive Care Med. 2001;27:1466-73.

35. Brathwaite $D$, Weissman $C$. The new onset of atrial arrhythmias following major noncardiothoracic surgery is associated with increased mortality. Chest. 1998;114:462-8.

36. Bender JS. Supraventricular tachyarrhythmias in the surgical intensive care unit: an under-recognized event. Am Surg. 1996;62:73-5.

37. Salman S, Bajwa A, Gajic O, Afessa B. Paroxysmal atrial fibrillation in critically ill patients with sepsis. J Intensive Care Med. 2008;23:178-83.

38. Arora S, Lang I, Nayyar V, Stachowski E, Ross DL. Atrial fibrillation in a tertiary care multidisciplinary intensive care unit-incidence and risk factors. Anaesth Intensive Care. 2007;35:707-713.

39. Knotzer H, Mayr A, Ulmer $\mathrm{H}$, et al. Tachyarrhythmias in a surgical intensive care unit: a case-controlled epidemiologic study. Intensive Care Med. 2000;26:908-14.

40. Annane $D$, Sébille $V$, Duboc $D$, et al. Incidence and prognosis of sustained arrhythmias in critically ill patients. Am J Respir Crit Care Med. 2008;178:20-5.

41. Goodman S, Shirov T, Weissman C. Supraventricular arrhythmias in intensive care unit patients: short and long-term consequences. Anesth Analg. 2007;104:880-6.

42. Seguin P, Signouret $T$, Laviolle B, Branger B, Mallédant $Y$.
The Journal of Critical Care Medicine 2015;1(4) • 145

Incidence and risk factors of atrial fibrillation in a surgical intensive care unit. Crit Care Med. 2004;32:722-726.

43. Aderka D, Sclarovsky S, Lewin RF, Arditti A, Agmon J, Pinkhas J. Life-threatening ventricular arrhythmias in septicemia. Isr J Med Sci. 1984;20:535-7.

44. Stamatis SM, Margariti A, Rizikou D, et al. Incidence and predictors of new-onset atrial fibrillation in noncardiac intensive care unit patients. Journal of Critical Care. 2014;29:1-5.

45. Schwartz A, Gurman G, Cohen G, et al. Association between hypophosphatemia and cardic arrhythmias in early stages of sepsis. Eur J Internal Med. 2002;13 :434-7.

46. Koyfman L, Brotfain E, Kutz R, et al. Epidemiology of new-onset paroxysmal atrial fibrillation in the General Intensive Care Unit population and after discharge from ICU. A retrospective epidemiological study. Anaesthesiology Intensive Therapy. 2015;47:309-14.

47. Seemann A, Boissier F, Razazi GK, et al. New onset supraventricular arrhythmia during septic shock: prevalence, risk factors and prognosis. Ann Intensive Care. 2015;5:27-30.

48. Aldhoon B, Melenovský V, Peichl P, Kautzner J. New insights into mechanisms of atrial fibrillation. Physiol Res. 2010;59:1-12.

49. Kühlkamp V, Schirdewan A, Stangl K, Homberg M, Ploch M, Beck $\mathrm{OA}$. Use of metoprolol $\mathrm{CR} / \mathrm{XL}$ to maintain sinus rhythm after conversion from persistent atrial fibrillation: a randomized, double-blind, placebo-controlled study. J Am Coll Cardiol. 2000;36:139-46.

50. Maisel WH, Rawn JD, Stevenson WG. Atrial fibrillation after cardiac surgery. Ann Intern Med.2001;135:1061-73.

51. Werdan $\mathrm{K}$, Schmidt $\mathrm{H}$, Ebelt $\mathrm{H}$, et al. Impaired regulation of cardiac function in sepsis, SIRS, and MODS. Can J Physiol Pharmacol. 2009;87:266-74.

52. Malik M, Camm AJ. Components of heart rate variability: what they really mean and what we really measure. Am J Cardiol. 1993;72:821-2.

53. Tracey KJ. The inflammatory reflex. Nature. 2002;420:853-9.

54. Engelmann MD, Svendsen JH. Inflammation in the genesis and perpetuation of atrial fibrillation. Eur Heart J. 2005;26:2083-92.

55. Maesen B, Nijs J, Maessen J, Allessie M, Schotten U. Postoperative atrial fibrillation: a maze of mechanisms. Europace. 2012;14:159-74.

56. Sulakhe PV, Sandirasegarane L, Davis JP, Vo XT, Costain WJ, Mainra RR. Alterations in inotropy, nitric oxide and cyclic GMP synthesis, protein phosphorylation and ADP-ribosylation in the endotoxin-treated rat myocardium and cardiomyocytes. Mol Cell Biochem. 1996;164:305-18.

57. Hung J, Lew WY. Cellular mechanisms of endotoxin-induced myocardial depression in rabbits. Circ Res. 1993;73:125-34.

58. Wu SN, Lue SI, Yang SL, Hsu HK, Liu MS. Electrophysiologic properties of isolated adult cardiomyocytes from septic rats. Circ Shock. 1993;41:239-47.

59. Zhong J, Hwang TC, Adams HR, Rubin LJ. Reduced L-type calcium current in ventricular myocytes from endotoxemic 
146 The Journal of Critical Care Medicine 2015;1(4)

guinea pigs. Am J Physiol. 1997;273:2312-24.

60. Abi-Gerges N, Tavernier B, Mebazaa A, et al. Sequentialchanges in autonomic regulation of cardiac myocytes after in vivo endotoxin injection in rat. Am J Respir Crit Care Med.
Available online at: www.jccm.ro

1999;160:1196-204.

61. Toweill D, Sonnenthal K, Kimberley B, et al. Linear and nonlinear analysis of hemodynamic signals during sepsis and septic shock. Crit Care Med. 2000;28:2051-57. 